\title{
O ILUSTRE ESCRAVO INÁCIO DA CATINGUEIRA E A SUA PELEJA CONTRA O IMPÉRIO DA ESCRAVIDÃO NO SERTÃO DA PARAÍBA
}

\author{
THE HONORABLE SLAVE INACIO OF CATINGUEIRA AND HIS SKIN AGAINST \\ THE EMPIRE OF SLAVERY IN THE SERTÃO OF PARAÍBA
}

Antonio Martins de Oliveira

Univ. Autônoma de Barcelona tonimartins4@yahoo.com.br

RESUMO: A historiografia paraibano da primeira metade do século XX, tentando contribuir com a construção governamental de uma boa imagem do Brasil no exterior, pintou um quadro irreal da sua escravidão no século anterior, negando o real papel do negro na produção econômica sertaneja. Esta prática, por um lado, seria um reflexo da cultura elitista sertaneja da época e, por outro, daria suporte a tal cultura, perpetuando-a até os dias atuais. No entanto, esta produção historiográfica começa a se redimir a partir de 1979, com o trabalho da professora Diana Galliza e, a partir de então, as teses de pós-graduação começam a refletir um novo olhar para o personagem negro na história da Paraíba. Inácio da Catingueira, um escravo artista da segunda metade do século XIX, se insere nesse contexto de negação historiográfica, mas, com o seu talento extraordinário e sua personalidade pacífica, sobreviveu a toda condição de subjugação e esquecimento, e se tornou um personagem ilustre para o seu povo.

Palavras chave: Inácio da Catingueira, Peleja no Sertão, Inácio e Romano.

\begin{abstract}
Paraiba's historiography in the first half of the 20th century, trying to contribute to the governmental construction of a good image of Brazil abroad, painted an unreal picture of its slavery in the previous century, denying the real role of blacks in the backlands economic production. This practice, on the one hand, would be a reflection of the elitist backcountry culture of the time and, on the other hand, would support such a culture, perpetuating it to the present day. However, this historiographical production began to be redeemed in 1979, with the work of Professor Diana Galliza and, from then on, the postgraduate theses begin to reflect a new look at the black character in the history of Paraíba. Inácio da Catingueira, a slave artist from the second half of the 19th century, is part of this context of historiographic denial, but, with his extraordinary talent and peaceful personality, he survived all conditions of subjugation and forgetfulness, and became an illustrious character for your people.
\end{abstract}

Key words: Inácio da Catingueira, Poetic Challenge in Sertão, Inácio and Romano. 


\section{1- INTRODUÇAO}

A produção historiográfica paraibana da primeira metade do século XX, em consonância com os anseios das elites empresariais e da política governamental de recuperação econômica do Estado, em plena crise da cultura canavieira e do tráfico internacional de escravos, então proibido pela Inglaterra, buscou dar sua contribuição na construção de uma boa imagem do Brasil no exterior, pintando um quadro irreal da sua escravidão no século anterior. Para tanto, produziu uma narrativa de negação do real papel do negro na produção econômica sertaneja, uma prática que, por um lado, refletia a cultura elitista sertaneja da época e, por outro, daria suporte a que essa cultura se perpetuasse até os dias atuais, produzindo enormes injustiças contra esse povo trabalhador e inovador da cultura brasileira.

Esta história começa a mudar quando, a partir de 1979, o trabalho de pesquisa da professora Diana Galliza é divulgado e começa servir de referência para a produção de trabalhos acadêmicos de pós-graduação, apresentando um novo olhar para o personagem negro na história da Paraíba. O historiador José Octávio vai definir essa fase da produção intelectual como Nova Historiografia Paraibana (MELLO, 1988).

Inácio da Catingueira, um escravo artista que viveu entre 1843 e 1879, período que nos interessa estudar aqui, se insere nesse contexto de negação historiográfica do personagem negro na segunda metade do século XIX, mas é resgatado pela memória de quem assistiu à sua propalada peleja poética com um fazendeiro da região, da qual foi vencedor, demonstrando, com o seu talento e sua capacidade de arguição, que todo o sistema de sustentação ideológica da escravidão, oriunda da Europa, era uma falácia! E, esta novidade, que tomaria conta das pessoas presentes ao evento, principalmente o grande público de negros escravos e alforriados, coincidiria com o momento histórico de mudanças na mentalidade popular do final daquele século e consagraria aquele personagem na memória da região até os dias atuais.

\section{2- A negação da escravidão na historiografia paraibana}

Estudos realizados nos anos de 1990, pela professora Diana Soares de Galliza, identificam, nos principais autores da historiografia paraibana, a negação da presença massiva do escravo negro no sertão e do seu emprego efetivo na produção econômica local, sob argumentos por ela questionados, dentre os quais o de que o negro no sertão seria usado apenas como um artigo de luxo pelos seus senhores, não como mão-de-obra nos labores das fazendas: "De um modo geral, os 
bistoriadores que analisaram a economia sertaneja desprezaram o papel desempenhado pelo escravo negro ou atribuíram-lhe pouca importância na organização do trabalho nessa região" (GALLIZA, 1979: p. 80). Por esta razão, seu trabalho é apontada, por José Octávio de Arruda Mello, como a culminância das “inspirações pró-negras na Nova Historiografia Paraibana” (MELLO, 1988: p. 122) e, realmente, hoje é possível comprovar essa afirmativa de Mello ao pesquisarmos sobre esse tema, pois verificamos a presença, direta ou indireta, de Galliza nas diversas teses de mestrado e doutorado, trazendo uma nova visão acerca da presença cativa africana no sertão paraibano, com um rico levantamento de dados históricos primários, buscados nos cartórios de cidades como Piancó e Pombal, dentre outras, além de outras fontes de pesquisa.

Vejamos os argumentos de dois principais autores questionados por Galliza.

I- $\quad$ Capistrano de Abreu (1853-1927):

Capistrano de Abreu declarou que a presença dos negros africanos no criatório se justifica, "não como fator econômico, mas como elemento de magnificência e fausto, apresentaram-se gradualmente como sinais de abastança” (GALLIZA, 1979: p. 80).

II- $\quad$ Irineu Joffily (1886-1964):

Para semelhante modo de vida só era adaptada a raça americana; a africana era inteiramente incapaz, e, por isso a maior parte do pessoal de uma fazenda era de raça indígena, havendo somente para o serviço doméstico nas principais, entre escravos de fábrica, alguns africanos (GALIZZA, 1979: p. 95)

Entre os argumentos para explicar “este facto, apparentemente estranho” destacou que foi devido ao "orgulho que tinhão algumas famílias de demonstrar opulência pelo número de cativos que possuíam” (GALIZZA, 1979: p.81)

A autora assegura que não encontrou subsídios que comprovassem a tese de que o escravo negro não teve desempenho na economia sertaneja e que sua presença houvera constituído apenas um "elemento de magnificência e fausto" no sertão paraibano, e cita algumas razões para isto:

Em primeiro lugar, o estilo de vida do sertão contraria a asseveração de que o negro no criatório fora, apenas, fator de ostentação. A maioria dos fazendeiros tinha uma vida simples. Os inventários denotam que predominavam as habitações de taipa e de baixo valor pecuniário. (...) As boas moradas construídas em tijolo, no valor de 2:000\$000 [2 contos de réis], como encontramos no inventário de Bento José da Costa, constituíram exceção (GALIZZA, 1979: pp. 86-7).

Por outro lado, Mello assevera que: 
Muito diferente era a situação do escravo do campo, pois para compensar o alto preço por que era adquirido, ou o elevado investimento com a sua criação, tinha que produzir muito e consumir pouco. A faina no campo era de sol a sol com ligeiros intervalos para o café e um frugal almoço. Voltavam com o sol posto para o jantar, mas o trabalho continuava pela noite a dentro... (MELLO, 1988: p. 49).

Para entendermos bem os argumentos de Mello, acima, precisamos saber o preço do escravo no período que nos interessa estudar: 1843-79. Para tanto, vejamos a tabela de preços do escravo negro masculino de 15 a 29 anos de idade, entre os anos de 1843 e 1875 :

\begin{tabular}{|l|l|}
\hline ANO & Preço em MIL RÉIS \\
\hline 1843 & 550 \\
\hline 1848 & 460 \\
\hline 1850 & 650 \\
\hline 1851 & 610 \\
\hline 1852 & 870 \\
\hline 1853 & 960 \\
\hline 1854 & 980 \\
\hline 1855 & $1: 200^{*}$ \\
\hline 1856 & $1: 700$ \\
\hline 1857 & $1: 450$ \\
\hline 1858 & $2: 000$ \\
\hline 1859 & $1: 800$ \\
\hline 1860 & $2: 030$ \\
\hline 1861 & $1: 750$ \\
\hline 1862 & $1: 860$ \\
\hline 1863 & $1: 920$ \\
\hline 1864 & $1: 970$ \\
\hline 1865 & $2: 000$ \\
\hline 1866 & $1: 500$ \\
\hline 1867 & $1: 700$ \\
\hline 1871 & $1: 770$ \\
\hline 1872 & 1.920 \\
\hline 1873 & $1: 600$ \\
\hline 1874 & $1: 000$ \\
\hline 1875 & $2: 200$ \\
\hline 1 & \\
\hline
\end{tabular}

*1 Conto e 200 Mil Réis

Fonte: GALLIZA, 1979: pp. 112-3

Estes dados nos dão a noção exata do poder capital do preço de um escravo, comparandoos com outro, expresso na seguinte frase: "As boas moradas construidas em tijolo, no valor de 2:000\$000, como encontramos no inventário de Bento José da Costa, constituíram exceção" (GALIZZA, 1979: p. 87). Ou seja, o preço de um escravo negro masculino, em 1875, era ainda menor do que o de uma casa de luxo no sertão! Dessa forma, os argumentos apresentados acima para desconstruir a ideia de que 
não houve escravidão no sertão paraibano, ou que, na pior das hipóteses, a escravidão teria sido algo brando, sem a rigidez e a crueldade que marcaram esse sistema desumano no Brasil, acreditamos que são suficientes para atestarmos que tal ideia não se baseia em dados históricos concretos e comprováveis, mas, possivelmente, em uma tentativa dos historiadores de amenizar tal realidade, em consonância com interesses governamentais, no sentido de limpar a imagem da Paraíba, e do Brasil, perante a opinião internacional que pressionava o país a extinguir sua escravidão. É isto que fica patente na fala do governador da Paraíba, Frederico de Almeida Albuquerque, em 1872:

\footnotetext{
A lei n $n^{\circ} 2.040$, de 28 de setembro do ano passado, recebida nesta província com unânime aprovação de seus habitantes, essa lei eminentemente sábia, que resolveu o importantíssimo e assaz difícil problema social da emancipação dos escravos pelo modo o mais convincente, sem abalo da propriedade agrícola, e sem comoções, extinguindo em um lapso de tempo não longo essa instituição que nos legaram os nossos maiores, mas que nos envergonharam perante o mundo civilizado, e retardava o progresso moral e material sem inconvenientes (GALLIZA, 1979: pp. 168-9)
}

Ou seja: "lei eminentemente sábia", nos remete à participação de intelectuais na sua elaboração; "que resolveu... pelo modo mais convincente": a quem e do que queria o governo convencer?; "sem abalo da propriedade", ou seja, sem atingir os interesses dos fazendeiros; "sem comocões", quer dizer, sem revoltas populares; “essa instituição que nos legaram os nossos maiores”, é o mesmo que dizer: a culpa não é nossa!; "que nos envergonharam perante o mundo civilizado": aqui vemos a preocupação do governo com a opinião internacional, que "retardava o progresso moral e material sem inconvenientes".

Infelizmente, vamos encontrar muitas tragédias na nossa história e, em anexo, explicações que encobrem suas reais razões, numa tentativa das classes dominantes de pintarem uma história "para inglês ver": entendamos melhor essa expressão.

\section{3- O declínio do sistema escravista no sertão paraibano}

O fim do trafico internacional de escravos, exigido pela Inglaterra em 1859, contrariando os interesses dos fazendeiros e do governo, provocaria o declínio do sistema escravista na Paraíba, o que forçaria o governo a criar alternativas para salvar a economia do Estado, então dependente da mão-de-obra escrava. Esta proibição, aliada à crise na cultura açucareira, no litoral, e a grandes secas, na região sertaneja, teria como solução o escoamento dos escravos para o mercado da região Centro-Sul, que se encontrava carente dessa mão-de-obra para o cultivo do café, devido, por um lado, à desvalorização do escravo no mercado local e, por outro, ao aumento do seu preço no mercado interestadual. Portanto, isto constituía uma medida para que os fazendeiros pudessem se desvencilhar de seus escravos e, ao mesmo tempo, obter renda para saudar suas dívidas (GALLIZA, 
1979; MONTEIRO, 1987). Dessa forma, a Paraíba foi perdendo seus escravos ano a ano, conforme o quadro abaixo:

\begin{tabular}{|l|l|}
\hline ANO & ESCRAVOS NA PARAÍBA \\
\hline 1852 & 28.566 \\
\hline 1872 & 21.526 \\
\hline 1884 & 19.778 \\
\hline
\end{tabular}

Fonte: GALLIZA, 1979: p. 36

O sertão, apesar de ser uma zona econômica dedicada à cultura de criatório, também sofreria o impacto da crise na zona açucareira, primeiro, porque grande parte do seu produto era destinada ao consumo no litoral, tanto na Paraíba como em Pernambuco, e, depois, porque boa percentagem da escravaria do Estado paraibano estava nessa microrregião, conforme o quadro:

\begin{tabular}{|l|l|l|}
\hline ANO & ESCRAVOS NO SERTÃO & $\mathbf{\%}$ \\
\hline 1852 & 9.558 & 33,46 \\
\hline 1872 & 8.221 & 38,19 \\
\hline 1884 & 8.083 & 40,87 \\
\hline
\end{tabular}

Fonte: GALLIZA, 1979: p. 54

Dessa forma, ou seja, enfrentando a crise econômica e as devastadoras secas ocorridas entre os anos de 1852 e 1884, os fazendeiros do sertão não poderiam, por um lado, usar seus escravos apenas como artigos de luxo, deixando de empregá-los nas atividades laborais diárias, e, por outro, deixar de obter renda com a venda dos escravos excedentes para pagar suas dívidas. Isto, além da mortandade e dos suicídios de negros, causados pelos maus tratos e pela fome, principalmente nos anos da "Grande Seca" (1877-79), explicaria essa diminuição do número de escravos na região (GALLIZA, 1979; MONTEIRO, 1987; BARREIRO, 2002). Em 1879 Inácio da Catingueira morre.

\section{4- Catingueira e o seu entorno}

Nesse período da segunda metade do século XIX, Catingueira era apenas um agrupamento de casas de taipa denominado Povoado de São Sebastião, pertencente a Piancó e localizado ao leste deste município, no caminho que leva à capital. No seu entorno já existiam Pombal, Patos e Teixeira, cidades mais importantes da região. Para entendermos Catingueira, precisamos entender a influência desse entorno.

Comecemos pelos dados relativos ao quantitativo de habitantes livres e escravos nestas cidades (com exceção de Teixeira), nos anos de 1852 e 1872: 


\begin{tabular}{|l|l|l|l|}
\hline $\mathbf{1 8 5 2}$ & LIVRES & ESCRAVOS & $\mathbf{0}$ \\
\hline Pombal & 4.183 & 915 & 20,2 \\
\hline Piancó & 7.894 & 997 & 12,2 \\
\hline Patos & - & 544 & - \\
\hline & & & \\
\hline $\mathbf{1 8 7 2}$ & LIVRES & ESCRAVOS & $\mathbf{\%}$ \\
\hline Pombal & 11.800 & 1.800 & 10 \\
\hline Piancó & 13.057 & 612 & 4,7 \\
\hline Patos & 13.265 & 830 & 6,2 \\
\hline
\end{tabular}

Fonte: GALLIZA, 1979: pp. 83-4

Como podemos ver, o número de escravos das principais cidades do entorno de Catingueira era bastante alto, considerando-se o baixo povoamento de livres na região. Isto implica a existência de uma forte economia local e um trânsito comercial significativo entre estas cidades, e é este contexto que propicia o surgimento do então Povoado de São Sebastião, situado exatamente na intersecção destas localidades.

\section{5- A história de Catingueira}

De acordo com Wilson Nóbrega Seixas, no seu livro "Viagem Através da Província da Paraíba", Luiz Antônio da Silva Nunes foi o primeiro governador da Paraíba a viajar por todo o Estado para reconhecer as condições de suas estradas e a estrutura dos seus municípios, objetivando otimizar o trânsito comercial para a capital. Essa tarefa foi levada a cabo no ano de 1860, época em que o meio de transporte eram cavalos e mulas, o que fez a comitiva governamental viajar por cerca de 30 dias, fazendo breves paradas para visitas, nas principais cidades, e também para descanso, nas fazendas distribuídas pelo caminho.

O caminho principal que ligava a capital ao sertão, no século XIX, fazia o seguinte percurso: CAPITAL - Santa Rita - Pilar - Ingá - Campina Grande - Cabaceiras - São João do Cariri Teixeira - (Fazenda Catingueira) - Piancó - Souza - Catolé do Rocha - Pombal - Patos - Santa Luzia - Alagoa Nova - Areia - Bananeiras - Independência - Mamanguape - CAPITAL (SEIXAS, 1985).

Esse registro de Wilson Seixas é fundamental para este trabalho, uma vez que não encontramos, na literatura afim, outra referência documental com estas informações. Ele põe em evidência a cidade de Teixeira, ignorada por outros autores e por diversos trabalhos acadêmicos estudados por nós, e nomeia a Fazenda Catingueira, localizando-a geograficamente, além de dar algumas de suas características e de identificar os seus donos, como se segue: 
açude, casa de vivenda coberta de telha com copiar e bem espaçosa (SEIXAS, 1985: p. 80).

Deve-se a Pedro Velho Barreto a colonização e fundação do hoje município de Catingueira. Segundo consta, com sua morte, a viúva Joana da Maia da Rocha ficou como tutora dos seus filhos órfãos, tendo nomeado como seus procuradores, no sertão, aos seus genros Manoel Moreira d'Alto e João Pereira de Oliveira, os quais requereram e obtiveram a confirmação de suas terras, que houve por compra ao senhorio da Casa da Torre da Bahia. (...) Com o desaparecimento mais tarde de dona Joana passou a propriedade Catingueira ao domínio dos seus filhos e netos (SEIXAS, 1985: p. 146).

E continua, Seixas, falando de um fato que marcaria a fundação da cidade:

Ainda vivia, em 1856, dona Joana, quando irrompeu em toda a Província uma epidemia do "cólera-morbus", tendo uma filha daquela senhora feito uma promessa a São Sebastião que, se [a Fazenda] Catingueira saísse livre daquele mal, faria uma doação de terra para patrimônio da capela a ser ereta com aquela invocação. A graça foi alcançada, mas a doação só se verificou mais tarde depois da morte de dona Joana da Maia, através do filho Francisco Alves de Abreu, na presença do padre Herculano. A família de Pedro Firmino da Costa também contribuiu em favor da construção da capela (SEIXAS, 1985: p. 146-7).

Luiz Nunes, no seu livro "Inácio da Catingueira: o gênio escravo", também relata a origem da cidade atribuindo os mesmos fatos fundacionais: a existência da fazenda Catingueira, o surto do cólera, a promessa a São Sebastião e a doação do terreno à Igreja:

A cidade de Catingueira teve a sua origem na fazenda organizada por Pedro Velho Barreto em meados do século XVIII, nos sertões de Piancó. Na segunda década do século passado [séc. XX] começou a adquirir expressão urbana com a construção das primeiras casas da povoação. Localizada às margens da estrada que liga as regiões de Piancó e Espinharas foi, aos poucos, se beneficiando da condição de pousada dos que transitavam por ali. A cura de uma pessoa acometida de cólera morbo, resultante de uma promessa feita a São Sebastião por um descendente de Pedro Velho Barreto, motivou a construção da capela que tinha como orago o santo a quem se atribuíram os milagres (NUNES, 1979: p. 23)

Este autor, no entanto, atribui a origem e denominação da cidade, não à Fazenda Catingueira, como afirma o primeiro, mas à suposta existência de uma árvore chamada catingueira, sob a qual os viajantes dos vales do Espinharas e do Piancó aproveitariam a paragem sombreada para descansar. Esta hipótese nos parece improvável, uma vez que carece de elementos históricos concretos para corroborá-la. O mais provável é a hipótese de Seixas, de que a Fazenda Catingueira deu origem e nome à cidade, para a qual elencamos alguns fatores concretos que sugerem sua maior veracidade:

I- $\quad$ O local faz a junção, até hoje, entre os vales do Espinharas e do Piancó; 
II- Os viajantes e comerciantes que passavam pelo local frequentavam as cidades do entorno: Teixeira, Patos, Pombal e Piancó, fazendo deste ponto um local de encontro, de descanso e, também, de comércio para as fazendas da região;

III- Há, ainda hoje, na localidade, um olho d'água perene, ao pé da serra, que serve à população da região, principalmente em tempos de grandes secas;

IV- É bastante provável que o local, sendo o limite das fazendas da região e cortado por caminhos de uso comum dos viajantes da região e das capitais da Paraíba e Pernambuco, com o tempo se tornara um povoado de trabalhadores das fazendas para estabelecer comércio com os ambulantes, além de obter notícias do Império;

V- Também é provável que a escolha das terras para doação à Igreja, e posterior fundação do povoado, tivera como motivação a pré-ocupação do espaço para estabelecimento do comércio;

VI- É razoável deduzir que a origem do nome do povoado e do escravo "Inácio da Catingueira" não tenha sido uma suposta árvore no meio do sertão, mas a Fazenda Catingueira, que tem sua existência documentada;

VII- Durante a breve vida do escravo Inácio, o nome do povoado era apenas "São Sebastião", só modificado para "São Sebastião da Catingueira” em 1887, bem posteriormente à sua morte, em 1879; seu nome, portanto, faria referência à fazenda: "Inácio da Fazenda Catingueira", não à cidade: "Inácio da Cidade Catingueira", ou a uma árvore: "Inácio da Árvore Catingueira".

Portanto, a hipótese de Seixas, apoiada por estes fatores, descarta o relato fundacional da cidade Catingueira com base na suposta existência da árvore catingueira, que teria servido de paragem aos viajantes da região e motivo para a denominação da localidade. Isto implica, também, que redefinamos o papel histórico do escravo Inácio em todo esse processo.

\section{6- O escravo Inácio da Catingueira}

Diferentes autores falam da existência de Inácio da Catingueira, tais como Câmara Cascudo, Padre Otaviano, Luiz Nunes, Linda Lewin e Graciliano Ramos, dentre outros. Isto comprova a existência histórica desse personagem, mas nem todos eles explicam, de forma aprofundada, sua sobrevivência a centenas de anos já passados de sua morte. Vejamos o que eles dizem e, de nossa parte, vejamos o que poderemos acrescentar. Primeiro, destacaremos as explicações de cada autor e, depois, apresentaremos nossas descobertas, feitas a partir da comparação de dados encontrados. 
Começando por Luiz Nunes, podemos verificar que esse autor vê no escravo Inácio um talento excepcional que, não obstante a diferença gigantesca entre escravo e senhor, que implica uma condição dramática no século XIX, o põe em perfeita igualdade com o fazendeiro, dono de escravos, e nos diz:

A cantoria realizada na antiga vila de Patos, se não foi tão prolongada no tempo, como quiseram alguns, ficou gravada para sempre na memória da gente sertaneja como acontecimento maior no gênero, em razão da reconhecida fama e assombrosa participação de excepcionais cantadores (NUNES, 1979: pp. 33-4).

Câmara Cascudo, por sua vez, elogia bastante o escravo, falando de suas qualidades, e nos diz que Inácio foi um:

Cantador lendário e citado orgulhosamente por todos os improvisadores do sertão. Seus dotes de espírito, a rapidez fulminante das respostas, a graça dos remoques, a fertilidade dos recursos poéticos, a espantosa resistência vocal, ficaram celebradas perpetuamente. Sendo negro e analfabeto, não trepidou enfrentar os maiores cantadores de seu tempo, debatendo-se heroicamente e vencendo quase todos. Foi o único homem que conseguiu derrotar Romano da Mãe d'Água, depois de cantarem juntos oito dias em Patos, luta que é a página mais falada nos anais da cantoria sertaneja (CASCUDO, 1939: p. 257).

Padre Otaviano, embora ainda refletindo a mentalidade racista da época, busca infundir uma reflexão crítica acerca das condições do escravo, e nos diz:

\footnotetext{
Por isso, estamos aqui reunidos, em torno de uma inteligência, bárbara sim, mas as suas chamas o vento do passado não conseguiu engolir. Inteligência que brilhou no cérebro de um escravo que, hoje, é maior e mais admirado do que o seu senhor. Aquele, grande e este, pequeno, humilhado pelo sainete aviltante da escravidão, é quem merece palmas da posteridade. Glorifica-se o escravo, e do senhor não se fala. (...) Ninguém, hoje, escreve a história de Catingueira sem falar de Inácio. Um negro cativo que imortalizou a sua terra! (OTAVIANO, 1948: p. 8)
}

Graciliano Ramos, em seu relato um tanto crítico, reconhece, não obstante, o fenômeno que representou o escravo Inácio, e nos diz que:

No interior da Paraíba há mais de meio século dois cantadores famosos, ouvidos com admiração e respeito em cidades e vilas: Inácio da Catingueira, preto, e Romano, branco, de boa família, cheio de fumaças. O negro, isento de leituras, repentista por graça de Deus, exprimia-se com simplicidade, na língua comum do lugar. O branco exibia conhecimentos: andara uns meses na escola e, em razão da palmatória e dos cascudos, saíra arrumando algarismos, decifrando por alto o mistério dos jornais e das cartas. Possuía um vocabulário de que não alcançava direito a significação e lhe prejudicava certamente o estro, mas isto o elevava no conceito público (RAMOS, 2002: p. 69). 
Linda Lewin, uma autora norte-americana que esteve em Catingueira para pesquisar a vida de Inácio e, segundo ela, teve acesso direto aos muitos documentos em poder dos descendentes do dono do Inácio, situa o personagem escravo no contexto das grandes mudanças por que passava a região, na segunda metade do século XIX:

\footnotetext{
Por que a coragem e audácia de Inácio nunca foram esquecidas? A memória coletiva indelevelmente registrou a essência do Texto Catingueira, mais do que do Texto Teixeira, porque se deu em sintonia com o momento histórico em Patos. As réplicas de Inácio agradaram um público em massa que havia começado a experimentar mudanças fundamentais na ordem social prevalecente, baseada historicamente nos "brancos da terra" que, enquanto proprietários de escravos, impunham uma deferência social externa, senão uma obediência interna. A receptividade popular à refutação de Inácio ao desdém aferroado de Romano merece, portanto, ser interpretada à luz da mudança social no sertão nos anos de 1870 (LEWIN, 1998: p. 20).
}

Em resumo, vemos que Luiz Nunes e Graciliano Ramos falam de igualdade entre os dois cantadores, o que, se falamos em talento, podemos concordar, mas, se falamos nos demais aspectos: condição social, estudos, família, liberdade, alimentação, vestimenta, segurança, trabalho, etc., esta igualdade estava infinitamente longe de existir! Já o Padre Otaviano e Linda Lewin falam que ele sobreviveu na história graças, por um lado, à sua capacidade criativa e seu talento individual e, por outro, ao contexto de fama que ele adquiriu com o seu trabalho. Estas considerações certamente que nos oferecem uma boa explicação para o fenômeno, porém queremos acrescentar outros elementos.

A partir da leitura e comparação de dados históricos, podemos afirmar que Inácio, desde menino, em contato com os comerciantes ambulantes de toda a região, fora aprendendo a raciocinar rápido e a negociar de forma inteligente com os clientes do seu senhor, o que, aliado à sua capacidade criativa e, certamente, brincalhona (uma característica dos repentistas emboladores atuais), conseguiria desenvolver o seu modo particular de trabalhar através da música e da simpatia. Isto transformaria, com o tempo, os seus clientes em público assistente, e lhe renderia a admiração de todos que, ao passarem por fazendas e povoados, até chegarem à sua cidade de destino, divulgariam as façanhas artísticas daquele jovem "Inácio da Fazenda Catingueira", espalhando sua fama por terras distantes, como afirma o padre Otaviano:

Inácio da catingueira não se tornou conhecido somente no sertão do seu nascimento. A sua fama de repentista varou o Estado, foi ao Ceará, ao Piauí, ao vale do Amazonas e se derramou para o sul, para Pernambuco, Alagoas, Bahia e o resto do Brasil (OTAVIANO, 1948: p. 9). 
Como já dissemos nesse trabalho, entendemos que o nome do nosso personagem era, na verdade, "Inácio da Fazenda Catingueira", fazendo alusão à fazenda a que ele provavelmente pertencia, antes da morte do seu primeiro senhor, Manuel Luiz. Aqui vamos detalhar as razões pelas quais defendemos essa hipótese.

São quatro as razões: 1- porque a Fazenda Catingueira fora a primeira fazenda fundada na localidade, após a morte do antigo sesmeiro Pedro Velho Barreto, e é a única próxima à localidade onde hoje se situa a cidade; 2- porque, conforme Wilson Seixas, a Fazenda Catingueira daria origem ao povoado que, mais tarde, tomaria o seu nome; 3- porque o Povoado de São Sebastião foi formado a partir da doação das terras à Igreja e, a princípio, recebera o nome do referido santo, permanecendo assim por toda a vida de Inácio; e, 4- porque, o lugar que era chamado de Fazenda Catingueira, hoje tem o nome do seu antigo fundador, [Sítio] Pedro Velho, o que significa que sua denominação perdera o sentido de ser, já que a cidade passou a ostentar o mesmo nome.

Só em 1887, bem depois da morte de Inácio, é que esse povoado, agora como Distrito, passaria a se chamar São Sebastião da Catingueira, o que implica admitir que essa mudança seria uma homenagem a Inácio. A cidade seria definitivamente chamada Catingueira apenas em 1933, o que oficializaria de uma vez por todas a importância de Inácio para a cidade, já que fica patente que ele é o motivo do seu nome. Ou seja, em outras palavras, é a cidade que é famosa por causa dele, não ele que seria famoso por causa dela.

Não obstante tudo isso, o coronel Firmino Ayres Albano da Costa, dono da Fazenda Bela Vista, ciente de que "Catingueira" era o nome de uma fazenda vizinha, propôs em lei, em 1890, que o então distrito passasse a ser denominado de Jucá, o que foi aprovado, mas bastante criticado, como se verifica nas palavras do padre Otaviano:

A esta vila de Catingueira um dia lhe mudaram o nome para Jucá. A desgraçada da política é que tem desses planos aberrantes das coisas justas. Nem os mais célebres monumentos históricos ela respeita. O Brasil atual é grande atestado do que afirmo. Há mudanças absurdas que se tornam criminosas. Atentados dos mais bárbaros ao nosso passado histórico, ofuscando-se tantas glórias para se perpetuar a memória execranda de inimigos do povo (OTAVIANO, 1948: p. 33).

Para elaborar um entendimento dessa atitude de Firmino Ayres, é importante salientar a posição social e política desse coronel, com certeza oposta à do escravo Inácio. O coronel residia em Catingueira, um simples povoado conhecido como a terra de um escravo negro, algo certamente desinteressante para alguém de sua estatura de líder político regional. Conforme Damião Lucena: 
Em 1913, quando registramos a nomeação do prefeito José Peregrino Filho, assinalando a mais duradoura administração da história de Patos, detectamos a influência política decorrente dos laços familiares, no fato de ser casado com uma filha do coronel Firmino Ayres Albano da Costa, cocunhado de Miguel Sátyro e amigo da família Dantas de Teixeira... (LUCENA, 2015: p. 43).

Ou seja, embora o fato acima tenha se verificado em 1913, evidentemente que essas relações familiares, sociais e políticas já existiam, ou se formavam, na época em que vivia Inácio.

É consenso entre Luiz Nunes, Linda Lewin e Padre Otaviano que o arranjo para que Inácio desafiasse, em cantoria, ao renomado violeiro Romano, fazendeiro de Mãe d'Água, então distrito de Teixeira, teria sido costurado principalmente pelo coronel Firmino Ayres. No entanto, entendemos que tal arranjo não teria sido voluntário, mas que teria sido forçado pelas circunstâncias, por duas razões: primeiro, devido à fama do escravo cantador, como atesta Otaviano: "Os habitantes deste e dos municípios vizinhos ansiavam por um encontro de Romano com Inácio" (OTAVIANO, 1948: p. 11), e, depois, devido a que o coronel precisaria dar uma satisfação aos seus amigos de Teixeira. Dessa forma, ao contrário do que afirma Linda Lewin, a expectativa do coronel era que o violeiro de Mãe d'Água humilhasse ao escravo de Catingueira, porque, provavelmente tal fato fortaleceria o início da construção de relações sociais e políticas com Teixeira e Patos, além de lhe favorecer perante os olhos do povo.

O Padre Otaviano afirma que a cantoria teria ocorrido em 1874, enquanto que Luiz Nunes diz que ocorrera em 1870. De nossa parte, vamos concordar com Nunes, por três razões.

A primeira, é que "Depois da morte de Ana Joaquina, em 1875, Inácio ganhou uma nova e última proprietária, sua filha Pastora Maria do Amor Divino" (LEWIN, 1998: p. 6). Ou seja, fica patente que ele havia falecido e que Dona Ana o teria herdado. A segunda, seria que, provavelmente o ano de 1874 tenha sido tenso, por um lado, pelo estado de saúde de Dona Ana e, por outro, pela preocupação da família com sua herança, já que o preço de um escravo naquele ano chegava à casa dos 2 contos e 200 mil réis! Além disso, certamente aquele foi um ano de muito trabalho na fazenda, o que impediria Inácio de ausentar-se. A terceira razão, seria que, em não estando Manuel Luiz vivo em 1874, a informação do evento nesta data entraria em choque com o verso poético do próprio Inácio: "Seu Romano eu sou cativo do sinhô Manuel Luizz...". Quer dizer, ele não poderia ser cativo de um defunto! Dessa forma, afirmamos a grande probabilidade de que a peleja tenha ocorrido realmente no ano de 1870.

O resultado da peleja foi que o escravo humilhou o fazendeiro, fato esse que consagraria definitivamente o escravo perante a opinião pública e o imprimiria para sempre na memória do povo e na história da Paraíba, apesar da posterior tentativa do coronel de reverter esse quadro 
favorável ao escravo e amenizar o seu problema diplomático com as elites locais através da mudança do nome da cidade para Jucá.

Assim, podemos afirmar que, desde as suas origens, até os dias atuais, a cidade de Catingueira tem Inácio como personalidade mais ilustre, por ter sido ele o seu cofundador, ajudando em sua economia e em sua caracterização cultural, e também por ele haver lhe dado o atual nome de Catingueira, induzindo, através de sua fama regional, a transferência dessa nomeação, que pertencia à fazenda do seu antigo senhor, para o primitivo Povoado de São Sebastião.

\section{7- O legado de Inácio}

Graciliano Ramos, autor que nasceu em 1892, afirma que "Os descendentes de Inácio da Catingueira cantam em voz baixa, para um número pequeno de criaturas" (RAMOS, 2002: p. 72). Esta asseveração é de um homem branco, de classe média, intelectual, nascido apenas 4 anos depois da chamada Abolição da Escravatura, em 1888, portanto, recém-saído do ambiente sociocultural escravista que reinou formalmente no país por séculos, mas que foi sistematicamente negado na historiografia da Paraíba, como vimos em Diana Galliza. Sua visão, por mais bem intencionada e embasada cientificamente, e talvez até por causa disso, não conseguia dimensionar a grandeza daquele homem, Inácio, circunstancialmente escravo.

Quem poderia imaginar que, enquanto centenas de escravos fugiam da degradação da vida no cativeiro e nos trabalhos forçados, aquele escravo "Inácio da Fazenda Catingueira" faria dessa sua realidade um motivo de resistência pacífica, retribuindo com arte e dignidade o que lhe davam com suor e sangue? E assim foi, escravo até o final de sua vida, embora haja quem afirme que ele fora alforriado.

Além do Padre Otaviano, Luiz Nunes e Linda Lewin atestarem que Inácio morreu na condição de escravo, também os fatos históricos demonstram que ele não teve sua carta de alforria. Tais fatos são de duas naturezas: macro e micro.

Como vimos, no início desse trabalho, a segunda metade o século XIX marcaria a Paraíba com uma grande crise econômica e, com o fim do comércio internacional de escravos, os fazendeiros, para saudarem suas dívidas, passariam a vender sua mão-de-obra cativa para o CentroSul, onde o auge da cultura cafeeira a absorvia ao preço unitário de 2:200\$000 rs (2 contos e 200 mil réis), valor de uma luxuosa casa de tijolos no sertão, no ano de 1875. Isto, portanto, configuraria um fator de dimensões macroeconômicas para inviabilizar a concessão gratuita de alforrias.

Ao nível micro, temos o fator "herança familiar". Após a morte de Manuel Luiz, antigo dono de Inácio, a viúva Ana Joaquina passa a ser sua dona que, por sua vez, falecendo em 1875, 
transmite o escravo como herança à sua filha Pastora Maria, esposa de Fidié Rodrigues de Souza. Isto está devidamente documentado e, portanto, demonstra que, se Inácio tivesse uma carta de alforria, seria do tipo condicional, ou seja, carta em que o escravo é obrigado a servir ao seu senhor e a seus parentes até a morte desses (GALLIZA, 1979: p. 156). Mas, como Inácio morreu antes dos seus últimos senhores, é evidente que ele nunca tivera acesso a qualquer tipo de carta de alforria.

Luiz Nunes afirma que a data do falecimento de Inácio seria 1879, e que a causa seria uma pneumonia. Linda Lewin, por sua vez, mantém esta data, mas afirma que a causa seria uma tuberculose. Já o Padre Otaviano, também que a causa teria sido a pneumonia, mas estende essa data para um incerto 1881-82. Para nós, analisando os fatos históricos que atestam a ocorrência de uma grande seca entre os anos de 1877 e 79, na qual vieram a perecer de fome milhares de pessoas escravas e livres (MONTEIRO, 1987; GALLIZA, 1979; BARREIRO, 2002), compreendemos que a definição da data de 1879 para sua morte é plenamente factível, mas que, lamentavelmente, ele teria sido uma das milhares vítimas fatais da "Grande Seca" do Nordeste. Ou seja, para não restar qualquer dúvida, acreditamos que Inácio teria morrido de fome!

A seca é um fenômeno natural, mas as tragédias não o são, uma vez que o ser humano tem plena capacidade intelectual e tecnológica de prever, evitar ou minorar tais situações. O problema está, portanto, na responsabilidade e no compromisso moral das autoridades competentes com a preservação da vida, seja do semelhante, seja do meio ambiente ou do planeta. Porém, desde aquela época são registradas notícias de omissão, ou até mesmo desvios, nas ações de socorro para minorar as situações causadas pelas secas e, dessa forma, evitar a fome e a morte de tantas pessoas inocentes (GALLIZA, 1979; MONTEIRO, 1987; BARREIRO, 2002; MARTINS, 1979). Não obstante, quando as tragédias ocorrem, as autoridades são sempre competentes em explicá-las como inevitáveis, tentando encobrir as suas reais razões, para que sua imagem não fique prejudicada perante a opinião pública e perante a história. Mas, o encobrimento da verdade não dura para sempre, e ela acaba aparecendo, não importa o tempo que leve.

Esta situação, infelizmente comum nos meios políticos e administrativos, corroborada pelos meios de produção cultural, pode nos ajudar a entender, mesmo que não se justifique, o porquê da negação da escravidão na historiografia paraibana, o porquê da tentativa de "apagar" o personagem do escravo Inácio da história de Catingueira, o porquê de se negar que Inácio viveu e morreu na condição de escravo, e o porquê de se ocultar um personagem tão importante na história de uma cidade.

Inácio, na sua imensurável humildade e tamanha grandeza de alma, lutou contra tudo isso, mas com a arma do talento e da simpatia, e esperou pacientemente a verdade prevalecer. Ele sempre foi escravo, sim, mas nunca lhe tiraram a liberdade do seu coração. Em seus versos poéticos, em 
anexo, registrados após a peleja com Romano e muito divulgados por cantadores e escritores, Inácio nunca pronuncia uma frase sequer de lamento pela sua vida difícil e sofrida, de rancor contra seus donos, de raiva contra Romano, de baixa autoestima por ser negro, a reclamação a Deus pela sua sorte, ao contrário, ele cofirma sua identidade de escravo, diz o nome do seu senhor, demonstra que tem autoestima elevada: "Eu sou negro confiado", e declara amor ao à sua terra.

Assim, podemos afirmar que o povo humildade de Catingueira, consciente ou inconscientemente, tem Inácio como personalidade mais ilustre da cidade, por ter sido ele o seu cofundador, ajudando em sua economia e em sua constituição cultural, e também por ele haver lhe dado o atual nome de Catingueira, induzindo, através de sua fama regional, a transferência dessa nomeação, que pertencia à fazenda do seu antigo senhor, para o primitivo Povoado de São Sebastião.

Portanto, pode ser que, sertanejos sofridos como são, "Os descendentes de Inácio da Catingueira cantam em voz, baixa...", como diz Graciliano Ramos, mas, até hoje ninguém nunca interrompeu o seu canto, nem esse canto é “...para um número pequeno de criaturas", porque ele se espalhou pelo Brasil e pelo mundo!

\section{CONCLUSÃO}

O questionamento feito à historiografia paraibana, da primeira metade do século XX, pela professora Diana Galliza, aliado a alguns trabalhos específicos sobre o personagem Inácio, e sua cidade de Catingueira, nos possibilita reconstruir a história de um grande fenômeno ocorrido no sertão: um escravo do sertão que abalou o sistema escravista, se tornou o mais ilustre representante de sua terra e perpetuou na historia sua mensagem/exemplo de resistência pacífica, de humildade, de perdão e de amor. O curto tempo que conviveu entre nós, 1843-1879, foi marcado por grandes revoltas populares, por diversas formas de resistência à escravidão, inclusive o suicídio, e pela organização de muitos quilombos, mas Inácio não era um revoltado e, apesar de sofrer todas as misérias praticadas pelo sistema escravista, não pregou a violência, a raiva, ou o rancor. Sua arma era a arte e a simpatia, e foi assim conquistou a todos os frequentadores das estradas de Patos, Piancó, Pombal e Teixeira, que, encantados com o jovem negro, levaram seu nome ao resto do mundo: Inácio da Catingueira!

Ainda hoje seus descendentes não o conhecem como deveriam, mas, como o próprio Inácio ensinou, é preciso trabalhar duro, com alegria, e esperar os resultados com o passar do 
tempo, porque a Verdade demora a aparecer, mas, com certeza, um dia aparece! Inácio traduz a imagem do povo sertanejo, e dos seus descendentes, que, embora oprimido pela aridez do coração egoísta dos donos do poder, têm sempre um sorriso a dar, um abraço amigo a oferecer, um cantinho da casa para quem necessitar, um pouquinho de feijão para repartir e uma reza ou um chá para curar.

É garimpando informações daqui e dali, conversando com as pessoas e pedindo ajuda a alguns, que, aos poucos, conseguimos acumular conhecimento suficiente para contribuir com a construção de um relato mais coerente e científico dessa esplêndida história, para que nos sirva de inspiração a nossas vidas.

\section{ANEXO}

Fragmento de domínio popular da Peleja de Romano com Inácio (leitura vertical)

Nêgo me diga o seu nome

Que eu quero ser sabedor, Se é solteiro ou casado, Aonde é morador, Se acaso for cativo,

Diga quem é seu senhor.

Eu sou muito conhecido, Aqui nesta ribeira Este é o seu criado Inácio da Catingueira. Dentro da Vila de Patos, Compro, vendo e faço feira.

Nêgo tu vieste a Patos Procurando quem te forre Volta pra trás, meu negrinho Que aqui ninguém socorre E quem cai nas minhas unhas Apanha, deserta ou morre.

Seu Romano eu vim a Patos Pela fama do sinhô Que disseram que era mestre E era rei de cantador Que dentro de um salão Tem discurso de um doutor.

Nêgo que andas fazendo Aqui nesta freguesia Cadê o teu passaporte 
A tua carta de guia

Aonde tá teu sinhô

Cadê a tua famia?

Seu Romano eu sou cativo, Trabalho pra meu sinhô Quando vou para uma festa Foi ele quem me mandô E quando saio escondido Ele sabe pronde eu vô

Ouvi bem a tua loa Mas não possa acreditá

Pois eu também tenho nêgo E só mando trabaiá Como é que teu sinhô

Vai te mandá vadiá?

Seu Romano eu sou cativo Trabalho pelo comum Dá descanso a seus escravo É gosto de cada um Meu sinhô tem muito nêgo Seu Romano só tem um

Nêgo, o meu martelo, Por bom ferreiro é forjado; Tanto ele é bom de aço, Como está bem temperado; A forja onde foi feito É toda de aço blindado.

Seu Romano eu lhe garanto Que resisto ao seu martelo Ao talho do seu facão, Ao corte do seu cutelo; Se eu morrer na peleja, Lhe vencerei no duelo

Nêgo, se eu te pegar Numa volta de caminho Eu te faço um agrado, Com o chicote um carinho Se a camisa for nova Só te deixo o colarinho

Sou abelha de ferrão Sou besouro de caboco, 
Se eu pegar o seu Romano, De um arrocho deixo rouco De lhe quebrar as canelas Só lhe deixar dois catoco

Nêgo você não topa Eu e Verisso, meu mano De mim vai apanhá mais Do que burro de cigano E se cantar com Verisso Apanha que chora um ano

Seu Romano eu sô escravo Do sinhô Mané Luiz Tanto corta como risca, Como sustenta o que diz Sou vigaro capelão E sacristão da matriz.

Nêgo se tu me cercar Com quatrocentos caifai Cem de uma banda, cem de outra

Cem adiante, cem atrai Isto é que é tapa que dou Isto é que é nêgo que cai.

Seu Romano inda não viu De Catingueira o arranco Se pensa que dá em mim Eu quero lhe falá franco Abra o olho, limpe a vista Nêgo também dá em branco

(...)

\section{BIBLIOGRAFIA}

BARREIRO, José Carlos. Imaginário e Viajantes no Brasil do Século XIX: cultura e cotidiano, tradição e resistência. São Paulo: UNESP, 2002.

GALLIZA, Diana Soares de. O Declínio da Escravidão na Paraíba - 1850-1888. João Pessoa: Universitária, 1979.

LEWIN, Linda. Um Conto de Dois Textos - Oralidade, História Oral: insulto poético em o “desafio" de Romano e Inácio em Patos (1874). Departamento de História, University of California, Berkeley, 1998. Tradução: Ana Catarina Morawska Vianna. 
LUCENA, Damião. Patos de Todos os Tempos: a capital do sertão da Paraíba. João Pessoa: A União, 1915.

MARTINS, Eduardo. Cardoso Vieira e o Bossuet da Jacoca: notas para um perfil biográfico. (APENSOS: Discursos na Câmara dos Deputados, 1879). João Pessoa: A União, 1979.

MELLO, José Octávio de Arruda. A Escravidão na Paraíba - Historiografia e História: preconceitos e racismo numa produção cultural. João Pessoa: A União, 1988.

MONTEIRO, Hamilton de Mattos. Nordeste Insurgente. São Paulo: Brasiliense, 1987.

OTAVIANO, Padre Manoel. Inácio da Catingueira. Conferência pronunciada em Catingueira a 13 de Maio de 1948.

RAMOS, Graciliano. Viventes das Alagoas: quadros e costumes do Nordeste. $18^{\circ}$ Ed. Rio de Janeiro; São Paulo: Record, 2002.

SEIXAS, Wilson Nóbrega. Viagem Através da Província da Paraíba. João Pessoa: A União, 1985. 